\title{
KONCEPCJA ZIELONEGO PORTU W DZIAŁANIACH STRATEGICZNYCH POLSKICH PORTÓW MORSKICH
}

\section{The green port concept in the strategic activities of Polish seaports}

\section{Sandra Żukowska}

Zakład Rozwoju Regionalnego, Instytut Geografii Społeczno-Ekonomicznej i Gospodarki Przestrzennej, Uniwersytet Gdański, J. Bażyńskiego 4, 80-309 Gdańsk e-mail: sandra.zukowska@phdstud.ug.edu.pl

iD https://orcid.org/0000-0003-4589-4063

\section{Tadeusz Palmowski}

Zakład Rozwoju Regionalnego, Instytut Geografii Społeczno-Ekonomicznej i Gospodarki Przestrzennej, Uniwersytet Gdański, J. Bażyńskiego 4, 80-309 Gdańsk e-mail: tadeusz.palmowski@ug.edu.pl

iD https://orcid.org/0000-0002-1644-7945

\section{Marcin Połom}

Zakład Rozwoju Regionalnego, Instytut Geografii Społeczno-Ekonomicznej i Gospodarki Przestrzennej, Uniwersytet Gdański, J. Bażyńskiego 4, 80-309 Gdańsk e-mail: marcin.polom@ug.edu.pl

iD https://orcid.org/0000-0001-7867-6236

Cytacja:

Żukowska S., Palmowski T., Połom M., 2021, Koncepcja zielonego portu w działaniach strategicznych portów morskich, Prace Komisji Geografii Komunikacji PTG, 24(3), 49-63.

Streszczenie: Artykuł prezentuje podejścia wybranych portów morskich do zrównoważonego rozwoju oraz prowadzenia polityki w oparciu o koncepcje zielonego portu. W aktualnych realiach rozwój portów morskich nie powinien skupiać się wyłącznie na tradycyjnej aktywności związanej z rozwojem zasobów portowych - rozwoju infrastrukturalnego czy suprastrukturalnego. Nowe formy działalności wychodzić powinny poza granice ich funkcjonowania i obejmować m.in. kwestie związane z otoczeniem społecznym i wrażliwością środowiskową. Wyniki badania obrazują priorytety działalności rozwojowej portów oraz wskazują obszary, które wymagają zwiększonej uwagi. Podjęcie działań w tych obszarach jest niezbędne w celu intensyfikacji działalności równoważącej korzyści ekonomiczne ze społecznymi i środowiskowymi.

Słowa kluczowe: zielony port, zrównoważony rozwój, port morski, port zrównoważonego rozwoju, csr

Abstract: The article presents selected seaports' approaches to sustainable development and policy-making based on the green port concept. In the current reality, the development of seaports should not only focus on traditional activities related to the development of port resources - infrastructural or suprastructural development. New forms of activity should go beyond the boundaries of their operation and include, inter alia, issues related to the social environment and environmental sensitivity. The survey results illustrate the priorities of port development activities and indicate areas that require increased attention. Action in these areas is necessary to enhance activities that balance economic, social and environmental benefits.

Keywords: green port, sustainable development, seaport, sustainable port, csr 


\section{Wstęp}

Porty morskie współcześnie to wysokospecjalizowane i wielofunkcyjne huby usługowe. Należą do kluczowych ogniw w globalnym, lądowo-morskim łańcuchu logistycznym. Są węzłami, które integrują różne formy transportu. Porty w sposób szczególny wpływają na swoje otoczenie. Zasadniczo pełnią rolę katalizatora rozwoju regionalnego stymulując rynek otoczenia portu. Porty morskie i ich zarządy, które odpowiadają za politykę rozwojową stanowią sferę biznesu, której podstawowym celem jest osiąganie wzrostu konkurencyjnego. Działania, nad którymi mają kontrolę skupiają się w szczególności na kształtowaniu infrastruktury i suprastruktury portowej, mającej na celu m.in. zwiększenie przepustowości, czego docelowym efektem jest wzrost masy przeładunkowej (Parola i in., 2017). Działania o charakterze infrastrukturalnym i suprastrukturalnym należą do tradycyjnych aktywności rozwojowych portów morskich.

Zazwyczaj rozwój portu utożsamiany był z jego rozwojem przestrzennym, w którym zachodziły ścisłe związki między aktywnością gospodarczą a przestrzenną. Rozwój przestrzenny portów oraz stałe unowocześnianie wyposażenia portowego stanowiły istotny czynnik wzrostowy. Współcześnie zaobserwować można postępującą transformację zachodzącą w gospodarce morskiej. W szczególności dotyczy ona portów morskich, w których dochodzi do rozszerzania aktywności rozwojowej poza wymienione tradycyjne sfery. Coraz bardziej widoczna jest stopniowa zmiana priorytetów uwarunkowana kwestiami środowiskowymi i społecznymi. Transformacja ta określona została terminem zazielenienia portów morskich (Sage-Fuller, 2018). Termin ten można rozumieć jako podejmowanie przez porty zintegrowanych aktywności na rzecz zmniejszania negatywnego oddziaływania, przestrzegania ścisłych zasad ochrony środowiska oraz zapewniania zwiększonego zorientowania na otoczenie społeczne. Wiąże się to z faktem lokalizacji dominującej części portów morskich w otoczeniu zwartych struktur miejskich (Sage-Fuller, 2018).

Celem artykułu jest zbadanie jak kształtuje się podejście krajowych portów morskich do zagadnień prośrodowiskowych, związanych z płaszczyzną społeczną, gospodarczą, środowiskową i przestrzenną w oparciu o przegląd i krytyczną analizę zamierzeń strategicznych' (Apanowicz, 2002). Dopełnieniem opracowania jest zbadanie pozycji i umiejscowienia

Dokumenty strategiczne, dalej zwane jako „strategie rozwoju", to podstawowe dokumenty dotyczące realizacji celów rozwojowych. Są one niezbędnym narzędziem prowadzenia zrównoważonej polityki wzrostu. koncepcji zielonego portu w planach rozwojowych portów objętych analizą.

\section{Współczesna specyfika portów morskich}

Aby określić aktualny stan portów morskich należy zwrócić uwagę na ewolucję związków zachodzących w ich funkcjonowaniu. Pierwotne porty morskie skupiały się na tradycyjnej działalności obejmującej zagadnienia transportowo-logistyczne związane z przeładunkami (Żukowska, 2021a). Do ich tradycyjnych funkcji zaliczało się m.in. rybołówstwo, transport czy przemysł portowy. Swoją działalnością nie wychodziły poza ustalone granice administracyjne i nie utrzymywały związków z otoczeniem. Przykładem tego są porty I generacji. W kolejnych generacjach dochodziło do separacji portu od miasta. Związki między rozwojem generacyjnym portów morskich a ich relacjami z otoczeniem bardzo dobrze obrazuje model B. Hoyla (1989). Wraz z rozwojem portów zachodziło coraz większe zorientowanie wobec otoczenia społeczno-przyrodniczego. Od lat 80. XX w. zaczął postępować proces odtwarzania ścisłych związków portowo-miejskich, który trwa do chwili obecnej (Żukowska, 2021a). Było to ściśle powiązane z rozwojem generacyjnym portów, w szczególności z ewolucją do znacznie rozwiniętych portów III generacji. Każda nowa generacja portów charakteryzuje się wyższym stopniem rozwoju i nowoczesności. Stanowiło to również podstawę do dalszej aktywności rozwojowej w kierunku IV generacji z perspektywą do V i VI (Żukowska, 2020; Żukowska, 2021b). Odtwarzanie związków portowo-miejskich oraz wzrost ukierunkowania na otoczenie obejmuje przede wszystkim zwiększoną odpowiedzialność za funkcjonowanie portu.

Porty morskie należą do głównych czynników determinujących funkcje miastotwórcze oraz regionotwórcze, które intensyfikują rozwój społeczno-ekonomiczny w różnych skalach przestrzennych (Palmowski, 1998). Mimo tej istotnej funkcji porty morskie powodują również znaczące szkody środowiskowe, do których zaliczyć można np. zanieczyszczenia powietrza, wody i gleby, hałas czy wibracje. Są to czynniki ujemnie oddziaływujące na otoczenie portu, w szczególności na pobliskie tereny zurbanizowane i gęsto zamieszkiwane przez lokalną ludność. Mieszkańcy sąsiednich dzielnic są szczególnie podatni na negatywne wpływy działalności portowej.

W celu minimalizowania negatywnego oddziaływania porty morskie zobligowane są do podejmowania strategicznych działań na rzecz ograniczania i eliminowania ujemnych efektów swojej pracy. Główne priorytety rozwojowe portów morskich, oprócz zwiększania swoich zasobów, powinny być skupione na podejmowaniu działań na rzecz poprawy jakości 
powietrza i wody, bezpiecznej utylizacji odpadów portowych, zrównoważonego zużycia energii, ograniczania wytwarzania hałasu i wibracji, zawiązywania relacji z otoczeniem społecznym czy działań na rzecz przeciwdziałania zmianom klimatu (ESPO..., 2021).

Wskazane priorytety należą do głównych determinant transformacji zachodzącej w przestrzeni gospodarki morskiej, która w szczególności obejmuje ekologizację (zazielenienie) transportu morskiego. Proces ten nabiera tempa z uwagi na m.in. występujące nastroje polityczne i społeczne związane z ochroną środowiska. Transport morski stanowi integralną część globalnego łańcucha logistycznego, ponieważ blisko 80\% obrotu międzynarodowego odbywa się drogą morską (Cheaitou, Cariou, 2019). Stanowi on również finansową alternatywę w stosunku do transportu lotniczego czy drogowego, tym samym wpływając na zwiększenie zainteresowania wyborem tego środku transportu przez gestorów ładunków.

Postępujące zainteresowanie i wzrost wykorzystywania transportu morskiego potęguje globalizacja handlu i obrotu międzynarodowego. W skali globalnej wzrasta świadomość dotycząca tego, że transport morski również należy do jednych z istotnych źródeł powstawania gazów cieplarnianych, wpływając tym samym na pogłębianie kryzysu klimatycznego oraz pogorszanie zdrowia ludności poprzez zanieczyszczenie powietrza. W szczególności problem ten dotyka ludności mieszkającej na obszarach przybrzeżnych o dużym natężeniu ruchu morskiego. Dla przykładu, niebezpieczne emisje z sektora transportu morskiego w 2018 r. wynosiły 13,5\% całkowitej emisji gazów cieplarnianych pochodzenia transportowego w Unii Europejskiej (EMTER, 2021). Szacuje się, że poziom krytycznych emisji zżeglugi morskiej do 2050 r. wzrośnie nawet o 50\% (Pérez-Lespier i in., 2018). Rosnąca świadomość problemu stanowiła impuls do podjęcia przez decydentów strategicznych działań na rzecz kontroli negatywnych emisji pochodzących z transportu morskiego. Zalicza się do nich m.in. działania Unii Europejskiej na rzecz redukcji emisji gazów cieplarnianych o 60\% do 2050 r. w transporcie, w tym transporcie morskim (Cheaitou, Cariou, 2019).

Do istotnych problemów żeglugi morskiej należy generowanie hałasu podwodnego przez pracę silników okrętowych oraz działania urządzeń maszynowych. Hałas ten może powodować znaczące szkody w ekosystemach morskich, szczególnie wśród takich ssaków morskich, jak: wieloryby, delfiny czy morświny (m.in. problemy z komunikacją, utrata słuchu, zmiany zachowania). W latach 2014-2019 hałas emitowany ze źródeł transportu morskiego wzrósł dwukrotnie. Największymi źródłami hałasu są kontenerowce oraz statki pasażerskie (EMTER, 2021)
Do kolejnych problemów z jakim zmaga się żegluga morska należy przenoszenie przez statki patogenów wodnych, czyli obcych gatunków, często inwazyjnych, mogącym zagrażać ekosystemom, gatunkom rodzimym i bioróżnorodności, w których zostaną umiejscowione. Gatunki te przemieszczają się poprzez przywieranie do kadłuba statku bądź umiejscowienie w wodach balastowych. Mogą one mieć także wpływ na pogorszenie zdrowia ludności lokalnej oraz negatywnie odbijać się na działalność gospodarczą (EMTER, 2021).

Transport morski generuje znaczące ilości odpadów morskich, które są niebezpieczne dla bioróżnorodności gatunków wodnych czy dla samych statków, ponieważ mogą powodować ich awarie i wypadki. Odpady te, często wyrzucane przez morze na brzeg, stanowią zagrożenie dla ludności mieszkającej na obszarach nadmorskich. Do takich przykładów zalicza się zawartości m.in. kontenerów, które zostały zagubione na morzu podczas sztormów. Z czasem ich poszycie ulega zniszczeniu i cała zawartość może wydostać się do wody. Jest to szczególnie niebezpieczne w przypadku, gdy kontenery zawierają niebezpieczne substancje czy materiały. Kolejną grupę odpadów stanowią zrzucane do wody odpady wytwarzane na statkach. Pomimo, że tego rodzaju praktyka jest niedozwolona i nielegalna (EMTER, 2021) jednak ciągle ma miejsce.

Problem zanieczyszczenia środowiska pochodzącego z transportu morskiego początkowo był marginalizowany (Lister, 2015). Po pierwsze, z uwagi na to, że działalność żeglugi morskiej nie była bezpośrednio widoczna przez ludność nadbrzeżną, co skutkowało niską świadomością charakteru jej negatywnych emisji. Po drugie, nie przykuwano znaczącej uwagi do wykorzystywania zasobów naturalnych obszarów morskich. Sytuacja ta aktualnie zmienia się i akweny morskie stają się przestrzeniami obejmowanymi coraz większą liczbą uwarunkowań prawnych oraz areną walk politycznych (Lister, 2015). Do zwiększenia widoczności skali oddziaływania żeglugi morskiej na środowisko przyczyniły się również katastrofy ekologiczne będące np. efektem wycieku ropy, czego spektakularny przykład stanowił wyciek ropy z tankowca Exxon Valdez u wybrzeży Alaski pod koniec lat 80. XX w. Jego następstwem było przyjęcie konwencji MARPOL na rzecz przeciwdziałania zanieczyszczeniu morza substancjami szkodliwymi (Davarzani i in., 2016). Warto zaznaczyć, że transport ropy oraz materiałów ropopochodnych charakteryzuje się silną tendencją wzrostową. Mając na uwadze istotny problem jakim jest zanieczyszczenie wód m.in. wyciekiem ropy naftowej i jej produktów, podejmuje się kroki w celu uniknięcia katastrof poprzez wykorzystanie narzędzi, takich jak monitoring satelitarny. Monitoring służy do identyfikacji możliwych rozlewów o różnych rozmiarach. 
Dzięki temu narzędziu udało się na morskich wodach Europy zlokalizować ok. 8 tys. możliwych wycieków, z czego ponad $40 \%$ potwierdzono jako faktyczne wycieki (EMTER, 2021).

Ekologizację (zazielenienie) transportu morskiego można rozumieć jako podejmowanie skoordynowanych działań na rzecz osiągania neutralności klimatycznej oraz zerowego poziomu emisji zanieczyszczeń pochodzących z jej działalności (Komisja Europejska, 2021). Działania w tym zakresie stanowią fundament budowania zrównoważonej niebieskiej gospodarki.

Wzrost zainteresowania ochroną środowiska w stosunku do żeglugi morskiej wskazuje, że to właśnie porty morskie mogą pełnić kluczową rolę w transformacji ekologicznej gospodarki morskiej na rzecz jej nisko- i zeroemisyjności. Mogą one również sprzyjać kształtowaniu zielonego łańcucha logistycznego poprzez ekologizację usług portowych (Notteboom i in., 2020). Porty morskie zobligowane zostały do stałej dywersyfikacji swojej oferty usługowej, polegającej przede wszystkim na zwiększaniu przepustowości poprzez rozwój swojej infrastruktury i suprastruktury. Wzrost ten odbywać się powinien bez generowania negatywnych następstw szkodzących środowisku (Pérez-Lespier i in., 2018). Porty morskie powinny dostosować się do aktualnych wyzwań związanych z kwestiami środowiskowymi i społecznymi w skali lokalnej, regionalnej i globalnej przy jednoczesnym zwiększaniu swojej wydajności operacyjnej, implementowaniu inteligentnych rozwiązań cyfrowych oraz poprawie efektywności energetycznej (Davarzani i in., 2016).

Zwiększona presja środowiskowa i społeczna dotycząca charakteru działalności portowej i negatywnego oddziaływania żeglugi morskiej zdecydowanie wpłynęła na postępowanie procesu zazielenienia portów morskich (Lam, Notteboom, 2014). Jak wskazano, rozwój zielonych portów intensyfikowany jest również przez transformację gospodarki morskiej, przede wszystkim ekologizację transportu morskiego. W planach na rzecz rozwoju niebieskiej gospodarki Komisja Europejska wskazuje na fakt, że to porty morskie mogą odgrywać znaczącą rolę w tej transformacji. Przypisuje się im pełnienie nowej roli centrów energetycznych (energetyki odnawialnej) dla rozwoju europejskiej gospodarki o obiegu zamkniętym, komunikacji oraz przemysłu (Komisja Europejska, 2021).

Zauważa się również wzrost zainteresowania wymiaru społecznego w stosunku do negatywnego oddziaływania na nią żeglugi morskiej. W szczególności chodzi tu o miejsca cumowania statków na styku miasta i portu. Strefa styku obejmuje płaszczyznę operacyjną portu morskiego oraz otoczenie miejskie w postaci zwartej zabudowy miejskiej. Ludność zamieszkująca najbliżej tego styku jest szczególnie narażona na zanieczyszczenia pochodzenia portowego. Statki wycieczkowe (cruisery) zazwyczaj zawijają bliżej centrów miast, a ich postój jest relatywnie dłuższy z uwagi na aspekty turystyczne. W większym stopniu niż statki towarowe są więc odpowiedzialne za negatywne oddziaływania na środowisko (Lee i in., 2019).

Zielone porty to przede wszystkim porty zrównoważonego rozwoju, które intensyfikują działania w czterech obszarach - społecznym, gospodarczym, środowiskowym i przestrzennym (ryc. 1). Intensyfikacja działań na rzecz zrównoważonego rozwoju wynika z aktualnych przemian. Termin zrównoważony rozwój, który pojawił się w latach 90. XX w., współcześnie rozumiany jest jako rozwój gospodarczy idący w parze z rozwojem społecznym nie szkodzącym środowisku, obecnym ani przyszłym pokoleniom. Jednak dopiero w ostatnich latach jego rola dynamicznie wzrosła za sprawą istotnych problemów, z którymi zmaga się ludność (Du i in., 2019). Zielone porty dążą do zmiany wzorców działania na bardziej zrównoważone. Ich celem jest zmniejszenie uciążliwości wobec środowiska i klimatu (EMTER, 2021). Podstawę stanowią działania na rzecz ograniczenia zanieczyszczeń różnej postaci, zmniejszania hałasu, eliminacji wibracji czy działania na rzecz osiągania efektywności energetycznej w oparciu o alternatywne i odnawialne źródła energii.

Działalność portów morskich w oparciu o koncepcje zielonego portu ma również zapobiegać i przeciwdziałać konfliktom na styku port-miasto. Zderzają się tu interesy portu związane z jego działalnością rozwojową oraz otoczenia miejskiego - społecznego, wrażliwego na jego oddziaływanie (Lam, Notteboom, 2014). Przyjmuje się, że zielone porty stanowią odpowiedź wobec oczekiwań społecznych, zwiększonej świadomości środowiskowej czy wyzwań gospodarczych obejmujących m.in. wzrost konkurencyjny. Istotna jest również odpowiedzialna społecznie postawa portów morskich, czyli ich dobrowolne uwzględnianie różnych grup interesariuszy w procesie rozwojowym (Dooms, 2019). Mogą one odgrywać szczególną rolę skupiającą się na kształtowaniu zrównoważonego rozwoju w przestrzeni gospodarki morskiej, jak i wykraczając poza nią (Żukowska, 2020, 2021b).

Na władzach portowych spoczywa pełna odpowiedzialność za prowadzenie działalności rozwojowej, mając na uwadze stan obecny oraz odpowiedzialność za stany w przyszłości, które będą generować. Termin ten jest stosunkowo młody (Oniszczuk-Jastrząbek i in., 2018, Lam, Notteboom, 2014). Zauważa się wzrostowy trend zainteresowania koncepcją działań rozwojowych portów morskich oraz przyjmowaniem tej koncepcji jako nadrzędnej polityki rozwojowej. Wpływ na to wywiera również rynek, ponieważ współczesna siła konkurencyjna portu wykracza poza jego wy- 
posażenie operacyjne i obejmuje to, w jaki sposób port dba o środowisko i swoje otoczenie. Społeczna i środowiskowa odpowiedzialność portu należy również do czynników przyciągania nowych inwestorów, partnerów handlowych czy gestorów ładunków (Lam, Notteboom, 2014). ności bądź zeroemisyjności funkcjonowania portu, prowadzenie odpowiedzialnej środowiskowo polityki rozwoju, wdrażanie zielonych polityk rozwojowych czy wykorzystywanie narzędzi proekologicznych do m.in. zarządzania portem. Do działań w obszarze przestrzennym zalicza się m.in. prowadzenie zrówno-

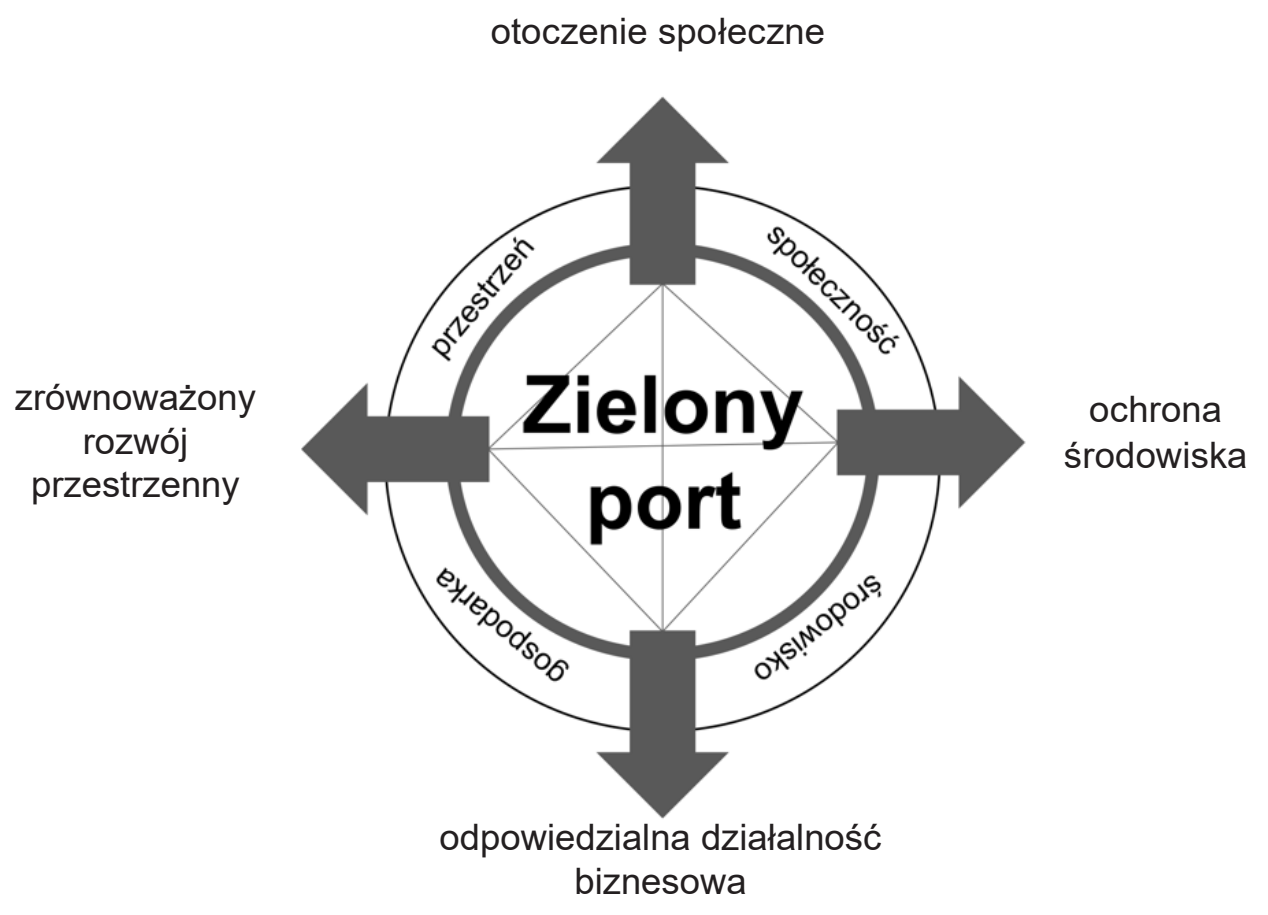

Ryc. 1. Model koncepcyjny zielonego portu.

Źródło: Opracowanie własne.

Do przykładowych aktywności zielonych portów w obszarze społecznym zalicza się m.in. dążenie do likwidacji dysproporcji w rozwoju społeczno-ekonomicznym, edukację i rozwój, partycypację i współdecydowanie, bezpieczeństwo czy rekreację. Do obszaru gospodarczego należy prowadzenie zrównoważonej działalności inwestycyjnej i rozwojowej, wdrażanie odpowiedzialnych praktyk biznesowych czy współpraca z otoczeniem społeczno-gospodarczym. W obszarze środowiskowym powinny znaleźć się działania związane z utrzymywaniem najwyższych standardów bezpieczeństwa i ochrony środowiska, udział w inicjatywach i partnerstwach środowiskowych, prowadzenie działań na rzecz zrównoważonego wykorzystywania zasobów portowych, poszukiwanie alternatywnych źródeł energii, wspieranie i rozwój transportu niskoemisyjnego, dążenie do zapewnienia niskoemisyj- ważonej ekspansji przestrzennej, rewitalizację i rekultywację terenów portowych, prowadzenie działalności inwestycyjnej uwzględniającej ochronę środowiska, kształtowanie ładu przestrzennego, prowadzenie racjonalnej gospodarki gruntami oraz zintegrowanego planowania portowo-miejskiego czy podejmowanie działań na rzecz włączania użytkowników do grona odpowiedzialnych za wykorzystywanie przestrzeni portowej, tak aby odbywało się to w sposób zrównoważony.

Podstawowa kwestia obejmuje równoważenie rozwoju biznesowego przy niskiej szkodliwości społecznej i środowiskowej. Działania w czterech obszarach powinny wykazywać współzależności oraz charakteryzować się związkami funkcjonalnymi. Dla zapewnienia faktycznego i skutecznego zrównoważonego wzrostu należy podejmować je systemowo, 
a nie fragmentarycznie. Istotą jest lokalność portu oraz jego środowiskowa wrażliwość. Zatem współczesna specyfika portów morskich to wyjście poza działalność inwestycyjno-rozwojową i tworzenie ścisłych związków z otoczeniem przy zachowywaniu kryteriów ochrony środowiska. Porty morskie powinny obrać rolę inicjatorów rozwoju społeczno-gospodarczego swojego otoczenia, brać czynny udział i samemu inicjować aktywność na rzecz poprawy warunków prośrodowiskowych.

\section{Obszar badania, metody analizy i źródła danych}

Obszar objęty badaniem obejmuje polskie porty morskie, które skupione są w trzech zasadniczych regionach - regionie Zatoki Pomorskiej i Zalewu Szczecińskiego, Środkowego Wybrzeża oraz regionie Zatoki Gdańskiej i Zalewu Wiślanego. Wyróżnia się dwa typy portów. Pierwszy to porty o podstawowym znaczeniu dla gospodarki narodowej, do których należą porty morskie w Gdańsku, Gdyni, Szczecinie i Świnoujściu (Ustawa o portach i przystaniach morskich). Porty te są szczególnie istotne z perspektywy gospodarczego rozwoju oraz podnoszenia konkurencyjności polskiego rynku w skali europejskiej i globalnej. Drugi typ dotyczy pozostałych portów, które wykazują charakter i oddziaływanie głównie w skali lokalnej i regionalnej (Polityka morska..., 2015).

W pracy wykorzystano metodę desk research, obejmującą analizę danych zastanych w postaci opracowań strategicznych portów morskich objętych analizą (Czarniawska, 2014).

W celu weryfikacji podejścia polskich portów do zagadnień prośrodowiskowych w swoich zamierzeniach strategicznych oraz tego w jaki sposób umiejscowiona została w nich koncepcja zielonego portu, podjęto próbę wyodrębnienia grupy poddanej badaniu. Delimitację wykonano na obszarze działania dwóch² jednostek administracji morskiej - Urzędu Morskiego w Szczecinie oraz Urzędu Morskiego w Gdyni (Obwieszczenie Ministra Infrastruktury...).

\footnotetext{
Na mocy Rozporządzenia Ministra Gospodarki Morskiej i Żeglugi Śródlądowej z dnia 15 stycznia 2020 r. zniesiono działalność Urzędu Morskiego w Słupsku. Był on jednym z trzech oprócz Urzędu Morskiego w Szczecinie i Urzędu Morskiego w Gdyni organem administracji morskiej w Polsce. Mienie będące w dyspozycji Urzędu Morskiego w Słupsku zostało podzielone między Urzędem Morskim w Szczecinie - część zachodniopomorska i Urzędem Morskim w Gdyni - część pomorska (Rozporządzenie Ministra Gospodarki morskiej i Żeglugi..., 2020).
}

W zakresie kompetencji terytorialnych Urzędu Morskiego w Szczecinie znajdują się kolejno porty morskie w: Szczecinie, Świnoujściu, Policach, Dziwnowie, Kamieniu Pomorskim, Wolinie, Mrzeżynie, Nowym Warpnie, Trzebieży, Stepnicy, Lubinie, Kołobrzegu i Darłowie. Morskie porty rybackie zlokalizowane są w Przytorze, Sierosławiu, Wapnicy i Dźwirzynie (Wykaz portów i przystani morskich w kompetencjach..., 2020). Dodatkowo funkcjonuje 12 przystani morskich, m.in. w Międzyzdrojach, Niechorzu czy Rewalu.

W zakres działania Urzędu Morskiego w Gdyni wchodzą kolejno porty morskie w: Gdańsku, Gdyni, Helu, Władysławowie, Elblągu, Pucku, Jastarni, Kątach Rybackich, Łysicy (Krynica Morska), Fromborku, Tolkmicku, Pasłęce, Łebie, Rowach i Ustce. Dodatkowo funkcjonuje 35 przystani, m.in. w Mechelinkach, Sopocie czy Stegnie (Wykaz portów i przystani morskich w obszarze..., 2021).

Zgodnie z aktualnymi wykazami portów i przystani morskich, będących w kompetencjach terytorialnych Dyrektora Urzędu Morskiego w Szczecinie oraz Dyrektora Urzędu Morskiego w Gdyni, krajowa przestrzeń portowa składa się z 32 portów morskich i morskich portów rybackich oraz 47 przystani morskich. Do analizy wybrano 32 porty morskie oraz morskie porty rybackie zlokalizowane na polskim wybrzeżu. Zestawienie krajowych portów morskich i przystani obrazuje ryc. 2.

Kolejną czynnością badawczą było sprawdzenie, ile spośród wybranych portów posiada dokumenty strategiczne określające uwarunkowania, cele oraz zasadnicze kierunki rozwojowe, stanowiące przedmiot badań (Ustawa o zasadach prowadzenia...).

Przegląd informacji zamieszczonych w przestrzeni wirtualnej pozwolił na wskazanie, że tylko 13 z 32 wyznaczonych podmiotów posiada opracowania strategiczne w formie strategii, planów bądź koncepcji rozwoju. Należą do nich: Port Morski w Szczecinie i Świnoujściu, Port Morski w Mrzeżynie, Port Morski w Kołobrzegu, Port Morski w Gdańsku, Port Gdynia, Port Morski w Helu, Port Morski w Władysławowie, Port Morski w Elblągu, Port Morski w Fromborku, Port Morski w Tolkmicku, Port Morski w Nowej Pasłęce i Port w Ustce. Podstawowym miejscem poszukiwań były oficjalne strony internetowe portów morskich. Opracowania te zostały przygotowane w latach 20072019. Na podstawie przeglądu zebranych dokumentów należy stwierdzić, że dominująca ich część nadal obowiązuje. 




Ryc. 2. Lokalizacja portów morskich i przystani na polskim wybrzeżu.

Źródło: Opracowanie własne.

\section{Prośrodowiskowe podejście}

i umiejscowienie koncepcji zielonego portu w działaniach strategicznych - studium przypadku polskich portów morskich

Pierwszą grupą objętą analizą są porty o wyłącznym znaczeniu lokalnym i regionalnym.

Port Morski w Mrzeżynie zlokalizowany jest w województwie zachodniopomorskim, u ujścia rzeki Regi. Jest to port o charakterze regionalnym, mający status portu rybackiego. Posiada on "Strategię Rozwoju Portu Morskiego Mrzeżyno" z 2010 r. Zasadnicze działania rozwojowe obejmują tu zagadnienia gospodarcze i przestrzenne. Skupiają się na działalności inwestycyjnej i modernizacyjnej, np. modernizacji i rozbudowie nabrzeży portowych oraz podejmowaniu aktywności mającej na celu aktywizację gospodarczą działalności portowej jaką jest rozwój funkcji turystycznej. Kwestie środowiskowe skupiają się na zabezpieczeniu standardów ochrony środowiska w porcie poprzez przygotowanie i wdrożenie planu gospodarowania odpadami i planu zwalczania zanieczyszczeń w porcie. Dodatkowo obejmują wyposażenie portu w środki zwalczające zanieczyszczenia oraz zapobiegające rozlewom (Strategia Rozwoju Portu Mrzeżyno, 2010).

Port w Kołobrzegu zlokalizowany jest w województwie zachodniopomorskim, u ujścia rzeki Parsęty. Stanowi istotny punkt węzłowy z perspektywy transportowej. W jego granicach usytuowano port handlowy, jachtowy, rybacki i wojenny. Kołobrzeski port posiada dwa opracowania strategiczne, do których zalicza się "Strategię Rozwoju Portu Morskiego Kołobrzeg” z 2010 r. oraz "Master Plan Portu Morskiego Kołobrzeg" z 2019 r. Do analizy wykorzystano pierwszy dokument, z uwagi na to, że drugi stanowi wyłącznie wskazanie wieloletniej perspektywy rozwoju inwestycyjnego z uwzględnieniem rozmieszczenia przestrzennego (Master Plan..., 2019). Działania strategiczne obejmują zasadniczo kwestie gospodarcze i przestrzenne. Występuje ścisły związek między działalnością inwestycyjną a zdynamizowaniem rozwoju funkcji pasażerskiej czy rybackiej w porcie. Szczególny nacisk położony został na podniesienie konkurencyjności portu poprzez m.in. dostosowywanie oferty usługowej (np. turystyczno-pasażerskiej) do potrzeb krajowych i zagranicznych (Strategia Rozwoju Portu Morskiego Kołobrzeg, 2010). 
Port morski w Helu to jeden z portów zlokalizowanych na Mierzei Helskiej. Posiada on „Plan Rozwoju Portu w Helu" z 2009 r., w którym podstawowe kierunki rozwoju skupiają się na rozwoju bazy ratownictwa morskiego, miejsc postoju jednostek rybackich czy bazy morskiej turystyki pasażerskiej z zapleczem usługowym. Działania strategiczne skupiają się na ożywieniu gospodarczym oraz przysposobieniu nowych komercyjnych funkcji związanych z portem. W celu realizacji zamierzeń strategicznych wskazywano na partycypację różnych grup interesariuszy, do których zaliczyć można władze miejskie, organizacje społeczne czy inwestorów. W tym przypadku port wciela się w rolę inicjatora, podejmującego dialog z otoczeniem społeczno-biznesowym w celu wspólnego określania spójnego sposobu zagospodarowania terenów portowych (Plan Rozwoju Portu w Helu, 2009).

Port morski we Władysławowie zlokalizowany jest u nasady Mierzei Helskiej. Stanowi port wielofunkcyjny - rybacki, turystyczny i przeładunkowo-składowy. Posiada dokument strategiczny o nazwie „Koncepcja rozwoju Portu Władysławowo" z 2019 r. Opracowanie strategiczne obejmowało ścisłe konsultacje z interesariuszami rozwoju portu - samorządem miejskim, inwestorami i ekspertami. Widoczne jest tu powiązanie zagadnień gospodarczych i przestrzennych. Główny akcent w zamierzeniach rozwojowych dotyczy modernizacji portu, do której zaliczyć można m.in. remont nabrzeży i nawierzchni dróg dojazdowych w celu poprawy bezpieczeństwa i zwiększenia wolumenu przeładunkowego. Obejmuje także rozbudowę przystani jachtowej oraz zaplecza socjalno-technicznego. W opracowaniu podejmowana jest również kwestia rewitalizacji nabrzeży oraz ich przysposobienie do nowych funkcji (Koncepcja rozwoju..., 2019).

Port morski w Ustce położony jest w północno-zachodniej części województwa pomorskiego, na środkowym wybrzeżu, w ujściu rzeki Słupia. Działalność portowa obejmuje funkcje - rybacką, przemysłową, transportową oraz wojskową. W dokumencie pt. "Strategia Rozwoju Portu Morskiego w Ustce do 2030 roku" istotną częścią była partycypacja, która obejmowała spotkania, konsultacje oraz badania ankietowe wśród lokalnej społeczności. To samo dotyczyło organizacji społecznych, sfery biznesu oraz władz miejskich. Dzięki temu udało się portowi wypracować spójne cele rozwojowe uwzględniające interesy różnych grup. Działania strategiczne jednoznacznie wskazują, że podstawą procesów rozwojowych jest tu zapewnienie zrównoważonego rozwoju. Dotyczy to kwestii społecznych (np. współpracy z otoczeniem dla osiągnięcia efektu synergii w działaniach rozwojowych), gospodarczo-przestrzennych (m.in. zdywersyfikowanie oraz zrównoważenie funkcjonalności portu czy stymulowanie rozwoju branż innowacyjnych) oraz środowiskowych (m.in. poprawa bezpieczeństwa oraz zapewnienie wysokich standardów środowiskowych). Port w działaniach strategicznych zorientowany jest na swoje otoczenie. Wynika to z jego centralnej roli w funkcjonowaniu i rozwoju miasta i regionu oraz kreowaniu działań rozwojowych. Osiągnięcie pozytywnych zmian w dobrobycie portu i otoczenia społeczno-gospodarczego stanowi strategiczny efekt realizowanej aktywności w porcie morskim w Ustce (Strategia Rozwoju Portu Morskiego w Ustce, 2019).

Port morski w Elblągu usytuowany został w województwie warmińsko-mazurskim, niedaleko ujścia do Zalewu Wiślanego rzeki Elbląg. Posiada typowy charakter rzeczno-morski. Przedmiotem jego działalności jest śródlądowa żegluga pasażersko-towarowa, jachting oraz żegluga morska bliskiego zasięgu (docelowo promowa). Port posiada "Strategię rozwoju portu morskiego w Elblągu" z 2019 r., która stanowi aktualizację dokumentu strategicznego z 2015 r. Powody aktualizacji obejmowały względy polityczno-prawne związane działaniami rządowymi. Dotyczyły one budowy kanału przez Mierzeję Wiślaną, otwierającego porty Zalewu Wiślanego na wody bałtyckie oraz modernizację toru wodnego do portu w Elblągu. Widoczne są powiązania gospodarcze i przestrzenne. Brakuje natomiast sformułowań ukierunkowanych na sferę społeczną, np. dotyczącą określenia związków z otoczeniem. Ta sama sytuacja dotyczy kwestii środowiskowych. Jednoznacznie widać, że ożywienie gospodarcze jest kluczowe dla działań rozwojowych portu. Podstawowy cel to zmiana jego charakteru lokalnego w regionalny i przekształcenie się w kluczowy port satelitarny dla portów morskich w Gdańsku i Gdyni (Strategia rozwoju portu morskiego w Elblągu, 2019).

Porty Zalewu Wiślanego to Tolkmicko, Frombork oraz Nowa Pasłęka. Największy z nich to port w Tolkmicku. Posiada on charakter rybacko-rekreacyjny oraz pasażerski. Przewiduje się w nim również funkcję logistyczno-magazynową i przeładunkową. Port we Fromborku składa się z portu rybackiego, przystani do obsługi jednostek białej floty oraz nieczynnej przystani pasażerskiej i jachtowej. Najbardziej na wschód wysuniętym portem w kraju jest port w Nowej Pasłęce. W jego skład wchodzi zespół przystani żeglarskich i rybackich.

Wymienione porty posiadają wspólny dokument strategiczny - "Strategię rozwoju portów i przystani morskich południowego brzegu Zalewu Wiślanego" z 2016 r. Zasadniczym celem opracowania było przygotowanie spójnej koncepcji rozwoju portów oraz przystani morskich na południowym brzegu Zalewu Wiślanego. Ponieważ wskazane tam działania i priorytety rozwojowe posiadają charakter uniwersalny, w przeprowadzonym badaniu przyjęto podejście grupowe do analizy wskazanych portów. Do kluczo- 
wych działań rozwojowych zalicza się aktywizację gospodarczą poprzez rozwój funkcji turystycznej, portowej (rybackiej, transportowej, przemysłowej) oraz logistyczno-magazynowej. Priorytetem jest również zapewnienie zrównoważonego transportu na południowym brzegu Zalewu Wiślanego. Wskazano na ścisły związek między działaniami gospodarczymi a przestrzennymi. Koncentrują się one m.in. na rozbudowie zaplecza portowego (głównie w celu rozwoju turystyki), działaniach rewitalizacyjnych oraz kształtowaniu ładu przestrzennego. Podjęte działania mają stymulować rozwój społeczno-gospodarczy otoczenia, wzrost jakości życia oraz likwidować dysproporcje w rozwoju społecznym. Działania w tym kierunku polegają m.in. na modernizacji i rozbudowie zaplecza dla zwiększenia bezpieczeństwa i poprawy warunków pracy rybaków (Strategia rozwoju portów..., 2016).

Drugą grupę stanowią porty o statusie podstawowego znaczenia dla gospodarki narodowej. Zespół portowy Szczecin-Świnoujście składa się z dwóch portów. Są to porty komplementarne, posiadające wspólny zarząd. Pierwszy z nich to port w Szczecinie zlokalizowany w głębi lądu, nad Odrą, w odległości ok. 70 km od wybrzeża (odległość mierzona po torze wodnym). Jest to port o charakterze uniwersalnym. Do głównych grup ładunkowych należą tu drobnica, ładunki masowe, węgiel czy zboże. Drugi to port w Świnoujściu położony w ujściu rzeki Świny do wód Zatoki Pomorskiej i nad otwartym morzem (terminal LNG). Port ten również posiada charakter uniwersalny, a najważniejsze typy ładunków obejmują drobnicę promową, paliwa, olej napędowy, zboża, pasze i rudy. Główne funkcje tych portów to funkcja transportowa, handlowa, dystrybucyjno-logistyczna i przemysłowa. Oba porty posiadają status portów klasy A, stanowiąc istotne punkty europejskiej sieci transportowej TEN-T. Obsługują żeglugę pasażerską - śródlądową i pełnomorską. Łączna powierzchnia portów wynosi $14394856 \mathrm{~m}^{2}$, z czego port w Szczecinie zajmuje 63\% powierzchni, a w Świnoujściu 37\%.

Omawiane porty posiadają wspólne opracowanie strategiczne - „Plan rozwoju Zarządu Morskich Portów Szczecin i Świnoujście S.A. do roku 2030". Działania w obszarze społecznym dotyczą wdrażania polityki $\mathrm{CSR}^{3}$, która obejmuje aktywności związane ze społeczną odpowiedzialnością biznesu - dbanie o swoje otoczenie lokalne oraz sprzyjanie rozwojowi regionalnemu. Do istotnych działań należy również m.in.

Corporate Social Responsibility to jedna z form strategii zarządzania, skupiająca się na podejmowaniu przez przedsiębiorstwo działalności rozwojowej uwzględniającej interesy społeczne i ochronę środowiska. Podstawowym celem strategii jest zapewnienie zrównoważonego rozwoju podmiotu oraz jego otoczenia. zakup statku pożarniczego, który ma pełnić nie tylko funkcję związaną z zapewnieniem bezpieczeństwa przyrodniczego, czyli ograniczanie i przeciwdziałanie zanieczyszczeniom (rozlewy olejowe i ich likwidacja), ale również z prowadzeniem akcji ratunkowych, zwiększając bezpieczeństwo społeczne. Występuje tu ścisły związek między podejmowaniem działań gospodarczych i przestrzennych (Plan rozwoju Zarządu Morskich..., 2019). Dotyczy to w szczególności aktywności rozwojowej i inwestycyjnej polegającej na poprawie dostępności do portów od strony zaplecza i przedpola, m.in. modernizacji oraz budowy wyposażenia infrastrukturalnego, suprastrukturalnego, rewitalizacji terenów portowych czy prowadzenia racjonalnej gospodarki gruntami portowymi.

Dodatkowo wyróżnić należy działania związane z wdrażaniem nowoczesnych systemów zwiększających poziom bezpieczeństwa operacyjnego czy stwarzaniem warunków do rozwoju innowacyjnych przemysłów portowych (offshore wind - sprzyjające produkcji zielonej energii). Podkreślić należy także zrównoważone podejście biznesowe dotyczące osiągnięcia konsensusu między realizacją priorytetów gospodarczych, przy uwzględnianiu wymogów związanych z otoczeniem lokalnym i sferą ochrony środowiska. W obszarze działań środowiskowych zasadniczym kierunkiem jest rozbudowa i modernizacja infrastruktury technicznej, która obejmuje sieci wodociągowe, kanalizację sanitarną i wód opadowych, zasilanie elektroenergetyczne, sieci teletechniczne, sieci wody przeciwpożarowej oraz bezpiecznego systemu odwadniania terenów. Podstawowym celem jest optymalizacja zużycia energii oraz zwiększenie bezpieczeństwa środowiskowego. Wyróżnić należy również działania na rzecz wdrażania infrastruktury dla zapewnienia zielonej energii z lądu do ładowania statków. Dzięki temu statki cumujące przy nabrzeżu będą mogły wykorzystywać wyłącznie zasilanie elektryczne z lądu. Rozwiązanie to zmniejsza negatywne oddziaływania statków oraz ogranicza emisję zanieczyszczeń powodowanych pracą siłowni okrętowych. (Plan rozwoju Zarządu Morskich..., 2019).

Zespół portowy Szczecin-Świnoujście jest również członkiem środowiskowej inicjatywy europejskiego sektora portowego - EcoPorts, którego zasadnicze działanie obejmuje budowanie zrównoważonej sieci obejmującej wymianę wiedzy i praktyk prośrodowiskowych, wspierających rozwój zielonych portów (EcoPorts, 2021).

Port morski w Gdańsku to port o charakterze uniwersalnym, który obsługuje różne grupy towarów - od kontenerów, paliw płynnych, masowych aż po produkty chemiczne. Port ten posiada kategorię A. Stanowi także kluczowy punkt sieci transportowej TEN-T. W skład portu wchodzi m.in. nowoczesny 
głębokowodny terminal kontenerowy - Deepwater Container Terminal (DCT), który umożliwia obsługę największych jednostek pływających na Bałtyku.

W porcie gdańskim wyodrębniono port wewnętrzny oraz zewnętrzny. Port wewnętrzny wyposażony jest w terminal kontenerowy, promowo-pasażerski, ro-ro, nabrzeże przeładunkowe samochodów osobowych, owoców cytrusowych, siarki oraz nawozów. Przystosowany jest również do przeładunków drobnicy konwencjonalnej oraz towarów masowych, np. zbóż, rudy, węgla czy wyrobów hutniczych (Zarząd Morskiego Portu Gdańsk S.A., 2021). Port zewnętrzny natomiast wyposażony jest w nabrzeża - paliwowe, węglowe, LNG, rudowe oraz nabrzeża terminalowe DCT. W tej części portu zlokalizowany został również Terminal Naftowy PERN, który umożliwia przyjmowanie i magazynowanie ropy naftowej. Port obsługuje ponadto ruch pasażerski, promowy oraz wycieczkowy. W relacjach z przedpolem port gdański obsługuje bezpośrednie połączenia kontenerowe z Azją (Zarząd Morskiego Portu Gdańsk S.A., 2021).

Port w Gdańsku posiada dokument strategiczny „Strategia portu Gdańsk 2030" z 2019 r. Podstawowe cele i priorytety zawarte $\mathrm{w}$ dokumencie dotyczą zapewnienia zrównoważonego oraz odpowiedzialnego rozwoju portu, który należy do najważniejszych węzłów transportowych w regionie bałtyckim. Jest on także inicjatorem i akceleratorem rozwoju społeczno-gospodarczego. W aktualizacji dokumentu z 2013 r. skupiono się przede wszystkim na wdrażaniu przez port polityki CSR - społecznej odpowiedzialności biznesu, inicjowaniu i promowaniu współpracy z nauką oraz wspieraniu $B+R$ (m.in. inicjowanie i aktywny udział w międzynarodowych wydarzeniach naukowo-gospodarczych, współpraca z otoczeniem naukowym - uczelniami, szkołami, wspieranie rozwoju start-upów) czy wykonywaniu działalności rozwojowej i inwestycyjnej w ramach formuły PPP (Partnerstwa Publiczno-Prywatnego). Zauważyć należy, że strategia zakłada wcielenie się przez port w rolę inicjatora innowacji, pełniącego rolę centrum kompetencji i nowych technologii, a także integratora nauki i sfery biznesu dla osiągania obustronnego wzrostu. Wszystko to oraz poszanowanie otoczenia i środowiska, w którym port funkcjonuje sprawia, że postrzegany jest on m.in. jako najlepszy pracodawca w północnej części kraju (Strategia Portu Gdańsk..., 2019).

Do przykładowych działań w obszarze społecznym należy zaliczyć ścisłą współpracę z metropolią trójmiejską, powiatami sąsiadującymi oraz województwem pomorskim w zakresie tworzenia optymalnych warunków wobec zrównoważonego rozwoju przestrzennego i społecznego. Gdański port w swoich działaniach strategicznych wciela się również w rolę mediatora pomiędzy sferą biznesu a otoczeniem, wpływając na przeciwdziałanie i eliminowanie konfliktów na styku port-miasto. Współpraca z otoczeniem jest niezbędna do osiągania efektów synergii. W obszarze gospodarczym dominują działania na rzecz zwiększenia uniwersalnej funkcji portu, którego wizja obejmuje stworzenie w gdańskim porcie europejskiego hubu logistyczno-dystrybucyjnego, innowacyjnego portowego kompleksu przemysłowego, jak i rozwoju morskiej turystyki wycieczkowej.

Z punktu widzenia rozwoju gospodarczego istotne jest podnoszenie i stałe umacnianie pozycji konkurencyjnej, szczególnie poprzez wdrażanie proekologicznych rozwiązań i wspieranie innowacyjnych branż (np. technologii offshore). Następnie ważna jest digitalizacja procesów zachodzących w porcie, w szczególności efektywne gospodarowanie zasobami związanymi z czasem pracy, zasobami ludzkimi, środkami finansowymi czy wdrażaniem polityki smart port \& smart city. Obejmuje ona wykorzystywanie inteligentnych rozwiązań w zakresie gospodarki, mobilności, zarządzania, środowiska czy ludności. Ma to na celu zwiększenie efektywności biznesowej portu przy jednoczesnym podniesieniu jakości życia w otoczeniu społecznym. Zachodzi ścisły związek między działaniami rozwojowymi w zakresie gospodarczym a przestrzennym. Zasadniczo obejmuje utrzymanie i modernizację zasobów portowych - infrastruktury i suprastruktury portowej, kształtowanie ładu przestrzennego czy zrównoważone gospodarowanie gruntami.

Port morski w Gdańsku obok zespołu portowego Szczecin-Świnoujście jest również członkiem sieci EcoPorts. W następstwie tego, działania wskazywane przez port w zakresie wzrostu biznesowego mają być podejmowane w sposób zrównoważony. Nie będą odbywały się kosztem społecznym ani środowiskowym. Ambitne plany portu gdańskiego zakładają przekształcenie go w jeden z najważniejszych zielonych portów w Europie. Dążenia te idą również w kierunku funkcjonowania zeroemisyjnego, w którym to aspekty środowiskowe determinować będą inwestycje terminalowo-produkcyjne. Zorientowanie na otoczenie podejmowane jest również poprzez wdrażanie narzędzi proekologicznych, tym samym wpływając na zmianę zachowań innych podmiotów w bardziej odpowiedzialnym i zielonym kierunku transformacji. Odbywa się to np. poprzez wprowadzanie rabatów dla armatorów wpływających do gdańskiego portu na podstawie indeksu ESI - Environmental Ship Index, który przedstawia wyniki statków morskich w zakresie osiągania niskoemisyjności (Environmental Ship..., 2021). Kolejne działania obejmują m.in. działalność inwestycyjną w zakresie wdrażania bezpiecznej i bezawaryjnej sieci wodociągowej, kanalizacyjnej, sanitarnej, punktów odbioru ścieków ze statków czy 
np. wdrażanie technologii zasilania statków z lądu (Strategia Portu Gdańsk..., 2019).

Ostatnim podmiotem objętym analizą jest port morski w Gdyni. Należy on do czterech polskich portów o podstawowym znaczeniu dla rozwoju gospodarczego. Port posiada charakter uniwersalny i kategorię A. Specjalizuje się w działalności przeładunkowej drobnicy, kontenerów, ładunków masowych - węgla i koksu, zbóż, ro-ro czy paliw. Stanowi kluczowy punkt węzłowy europejskiego korytarza sieci TEN-T w relacji Bałtyk-Adriatyk. Gdyński port posiada silną pozycję konkurencyjną w regionie bałtyckim, w szczególności w obrocie kontenerowym, ro-ro czy promowo-pasażerskim. Docelowo jednak jego wizja rozwoju obejmuje stanie się portem oceanicznym (Zarząd Morskiego Portu Gdynia S.A., 2021).

Port posiada dokument przyjęty i opublikowany w 2014 r. - „Strategia rozwoju Portu Gdynia do 2027 roku". Podstawą dla działań rozwojowych jest zapewnienie zrównoważonego rozwoju sektora usługowego portu, który obejmuje rozwój infrastrukturalny i suprastrukturalny, wspieranie dobrych praktyk biznesowych, zorientowanie na otoczenie, w którym funkcjonuje i na które oddziałuje oraz zapewnienie najwyższych standardów bezpieczeństwa środowiskowego. Konsekwentnie od lat gdyński port wykonuje zieloną politykę - green ports (zielonego portu) w podejmowanych działaniach na rzecz otoczenia oraz działalności inwestycyjno-rozwojowej. Szczególnie podkreślony został rozwój współpracy w relacjach port-miasto oraz troska o swoje otoczenie. Istotną rolę pełni tu polityka CSR w działaniach strategicznych. Polityka społecznej odpowiedzialności w przypadku Portu Gdynia jest o tyle istotna, że port i miasto stanowią wyróżniający się przykład złożonej korelacji rozwoju portu morskiego i wznoszącego się z nim miasta. Pełne zorientowanie na otoczenie i podejmowanie odpowiedzialnych decyzji równoważących korzyści ekonomiczne ze społecznymi i środowiskowymi są tu niezwykle istotne dla zapewnienia efektu synergicznego wzrostu ich obu. Społeczna odpowiedzialność portu obejmuje zagadnienia związane ze zrównoważonymi praktykami biznesowymi, odpowiedzialnością środowiskową, utrzymywaniem pozytywnych relacji z otoczeniem społecznym oraz zapewnianiem przyjaznego środowiska pracy (Strategia rozwoju Portu Gdynia..., 2014).

Kolejnym, bardzo ważnym elementem społecznej odpowiedzialności portu jest ścisła współpraca z otoczeniem naukowym i innymi instytucjami. Działania te dotyczą możliwości prowadzenia projektów badawczo-rozwojowych, tworzenia forum wymiany wiedzy i dobrych praktyk oraz umożliwienie poszerzania umiejętności praktycznych poprzez praktyki, szkolenia czy seminaria. Zorientowanie na otoczenie przejawia się również poprzez zapewnienie społeczności lokalnej możliwości do rekreacji związanej z portem, do których zaliczyć można m.in. organizowanie wydarzeń o charakterze kulturalnym czy sportowym. Dzięki nim mieszkańcy Gdyni mają możliwość bezpośredniego poznania działalności portu, który w istotny sposób wpływa na kształtowanie przestrzeni gospodarczej miasta. Dotyczy to również działań na rzecz poprawy stanu zdrowotnego otoczenia społecznego (Żukowska, 2020).

Zapewnienie zrównoważonego rozwoju usługowego w porcie obejmuje ścisłe powiązanie kwestii gospodarczych i przestrzennych - działalności inwestycyjnej i modernizacyjnej, m.in. w zakresie rozwoju dostępu do portu od strony przedpola i zaplecza (np. kolejowego), zwiększenia przepustowości oraz wzrostu możliwości przeładunkowych - wolumenu przeładunkowego. Dotyczy to także poszukiwania nowych terenów rozwojowych intensyfikujących wzrost gospodarczy, jednocześnie odciążając przestrzeń miejską z nadmiernego ruchu portowego i okołoportowego (przykładem jest Dolina Logistyczna stanowiąca docelowe zaplecze operacyjno-logistyczne portu).

Prowadzenie polityki green port (zielonego portu) obejmuje zrównoważone inwestycje, do których zalicza się m.in. nowy, publiczny terminal promowy przy nabrzeżu Polskim, określany mianem zielonego terminala. Po raz pierwszy w kraju zastosowano tu przyłącza elektryczne do zasilania z lądu promów cumujących przy terminalu promowym.

Implementowany system onshore power supply będzie miał wpływ w szczególności na ograniczenie zanieczyszczeń powietrza (np. eliminacęe emisji dwutlenku węgla do atmosfery), a także redukcję drgań i wibracji generowanych przez jednostki pływające. Do korzyści rozwiązania zaliczyć można również wydłużenie żywotności silników na statkach oraz poprawę komfortu pracy załogi (Zarząd Morskiego Portu Gdynia S.A., 2021).

Do przykładowych innowacyjnych rozwiązań zaliczyć można także nowoczesny model finansowania rozwoju infrastruktury portowej, który dotyczy wzrostu zaangażowania samych użytkowników w ponoszenie kosztów użytkowania wyposażenia portowego, kierując się podstawową zasadą "użytkownik płaci”. Jest to dobry przykład wzbudzania wśród użytkowników postaw odpowiedzialności na rzecz poprawy warunków środowiska przyrodniczego.

Gdyński port dba o wysoką jakość środowiska poprzez m.in. prowadzenie monitoringu środowiskowego (Strategia rozwoju Portu Gdynia..., 2014). W zakres prowadzonego monitoringu wchodzi pomiar poziomu hałasu, pomiary substancji zanieczyszczających wody basenów portowych, badanie jakości wód podziemnych, poziom zanieczyszczenia gleby czy 
analizy czystości osadów dennych (Zarząd Morskiego Portu Gdynia S.A., 2021).

\section{Dyskusja wyników przeprowadzonego badania}

Wyniki dotyczące prośrodowiskowego podejścia wybranych portów morskich w zamierzeniach strategicznych, obejmujących kwestie społeczne, gospodarcze, środowiskowe i przestrzenne, przedstawione zostały w tab. 1. łeczno-środowiskowym. Szczególnie widoczne było to w przypadku małych portów, o typowym charakterze lokalnym i regionalnym, dla których m.in. ożywienie gospodarcze jest strategicznym celem rozwojowym. Wnioski ten są zgodne z obserwacjami T. Michalskiego (2020), który zauważa, że krajowe małe porty zmagają się z licznymi problemami. Zalicza się do nich znikomą działalność przeładunkową i stale spadające obroty ładunkowe, epizodyczną rolę przewozów pasażerskich, znikomą działalność związaną z rybołówstwem

Tab. 1. Prośrodowiskowe działania społeczne, gospodarcze, środowiskowe i przestrzenne prowadzone przez porty morskie objęte analizą.

\begin{tabular}{|c|c|c|c|c|}
\hline Nazwa portu / obszar & Społeczne & Gospodarcze & Środowiskowe & Przestrzenne \\
\hline Port morski w Mrzeżynie & - & $\mathrm{x}$ & $x$ & $x$ \\
\hline Port morski w Kołobrzegu & - & $x$ & - & $x$ \\
\hline Port morski w Helu & $x$ & $x$ & - & $x$ \\
\hline Port morski we Władysławowie & $x$ & $x$ & - & $x$ \\
\hline Port w Ustce & $x$ & $x$ & $x$ & $x$ \\
\hline Port morski w Elblągu & - & $x$ & - & $x$ \\
\hline Port we Fromborku & \multirow{3}{*}{$x$} & \multirow{3}{*}{$\mathrm{x}$} & \multirow{3}{*}{-} & \multirow{3}{*}{$x$} \\
\hline Port w Tolkmicku & & & & \\
\hline Port w Nowej Pasłęce & & & & \\
\hline Port morski w Szczecinie & \multirow{2}{*}{$\mathrm{x}$} & \multirow{2}{*}{$\mathrm{x}$} & \multirow{2}{*}{$\mathrm{x}$} & \multirow{2}{*}{$\mathrm{x}$} \\
\hline Port morski w Świnoujściu & & & & \\
\hline Port morski w Gdańsku & $x$ & $x$ & $x$ & $x$ \\
\hline Port morski w Gdyni & $x$ & $\mathrm{x}$ & $\mathrm{x}$ & $x$ \\
\hline
\end{tabular}

Źródło: Opracowanie własne na podstawie materiałów rozproszonych.

Na podstawie informacji zawartych w tab. 1 wyraźnie widać, że kwestie gospodarcze i przestrzenne należą do najczęściej uwzględnianych obszarów rozwojowych w działaniach strategicznych portów objętych analizą. W większości opracowań aspekty gospodarcze i przestrzenne były ze sobą ściśle powiązane. Obejmowało to m.in. wzrost gospodarczy uzależniony od działalności inwestycyjnej i modernizacyjnej wyposażenia portowego. W mniejszym stopniu niż działania z obszaru gospodarczo-przestrzennego podejmowane były prace związane z obszarem spo- i przemysłem, które wspólnie mają wpływ na regres ich funkcji. Działalność mająca na celu aktywizację gospodarczą i poszukiwanie nowych szans rozwojowych, ze szczególnym uwzględnieniem turystyki, ma dla nich priorytetowe znaczenie (Szymańska, Michalski, 2018).

Do modelowych przykładów projektowania działań prośrodowiskowych zorientowanych na otoczenie oraz uwzględniających cztery "zielone składowe" zagadnienia społeczne, gospodarcze, środowiskowe i przestrzenne - zaliczają się przede wszystkim porty 
o podstawowym znaczeniu dla gospodarki narodowej - zespół portowy Szczecin-Świnoujście, porty w Gdańsku oraz w Gdyni. Ich rozwój determinowany jest uwarunkowaniami wewnętrznymi oraz zewnętrznymi, które obejmują kwestie ekonomiczne, legislacyjne i ochrony środowiska. Zauważa się, że wzrost kooperacji z bliskim otoczeniem społeczno-gospodarczym pozytywnie stymuluje rozwój oraz znacząco wpływa na zapewnienie efektu synergii portu i miasta. Bardzo ważna jest również świadomość i odpowiedzialność środowiskowa portów, które mogą również skutecznie przeciwdziałać występującemu kryzysowi klimatycznemu. Pozytywnym wyjątkiem jest port regionalny Ustka, który podejmuje zbieżne działania podobne do portów w Szczecinie-Świnoujściu, Gdańsku czy Gdyni. Pokazuje on, że mniejsze porty również mogą prowadzić działalność rozwojową w oparciu o politykę zrównoważonego rozwoju.

Prośrodowiskowe aktywności portów objętych analizą to zasadniczo ich oddolne i dobrowolne działania, które wspierane są przez samorząd lokalny i regionalny. Tezę tę potwierdzają obserwacje T. Bocheńskiego i in. (2021), którzy podkreślili ten fakt, a także wskazali, aby działania te nie były fragmentaryczne, a systemowe, że to władze państwowe, które koordynują krajową politykę morską powinny pełnić rolę inicjatora i regulatora ku zwiększeniu działań prośrodowiskowych w portach morskich. Wyraźnie widać, że niezbędna jest większa reakcja państwa w zakresie zazieleniania polskich portów.

W analizie nie uwzględniono strategicznego portu o charakterze regionalnym, jakim jest Port Morski w Policach, usytuowany między 45 a $50 \mathrm{~km}$ toru wodnego Świnoujście-Szczecin. Pod względem wielkości przeładunków stanowi on czwarty port w Polsce. Pod względem powierzchni nie ustępuje portom o podstawowym znaczeniu dla gospodarki narodowej. Port Police składa się z czterech terminali przeładowujących towary masowe. Obsługuje on Zakłady Chemiczne „POLICE” S.A. Budowa nowoczesnego kompleksu „Polimery Police” wpłynęła na budowę nowego terminalu morskiego do obsługi statków morskich - gazowców. Od strony toru wodnego port jest pogłębiany. Dla dalszego jego rozwoju ogromne znaczenie będzie miała budowa połączenia kolejowego, które umożliwi dojazd pociągów bezpośrednio do portu.

Nieuwzględnienie portu w analizie wynikło z trudności w dostępie do jego dokumentów strategicznych, które stanowiły przedmiot badania. Są jednak symptomy wskazujące, że port ten podejmuje działania zbieżne dla portów o podstawowym znaczeniu dla gospodarki i stara się prowadzić działania rozwojowe z troską o środowisko i otoczenie. Przeprowadzone badania uwidaczniają niskie pokrycie krajowych portów planami strategicznymi, które stanowią podstawowe narzędzie niezbędne do ich zrównoważonego rozwoju.

\section{Podsumowanie}

Porty morskie to podmioty, które są szczególnie podatne na oddziaływania mające zasadniczy wpływ na kształtowanie ich działalności. Do aktualnych czynników należy m.in. zwiększona świadomość ekologiczna, szczególnie społeczności z otoczenia portowego czy partnerzy biznesowi i klienci. Coraz częściej preferują oni opcje bardziej zielone i zrównoważone, dzięki czemu wpływają na kształtowanie zielonego łańcucha logistycznego.

W problematyce środowiskowej i społecznej odpowiedzialności portów morskich pojawia się koncepcja zielonego portu, która stanowi odpowiedź na współczesne wyzwania portów morskich w celu zapewnienia zrównoważonego i odpowiedzialnego wzrostu.

Tak prowadzona polityka rozwojowa wychodzi poza zapewnienie np. bezpieczeństwa związanego z działalnością infrastrukturalną i suprastrukturalną. Tradycyjne podejście do wzrostu, związane wyłącznie z działalnością inwestycyjną i orientacją na klienta, nie wystarcza do kształtowania znaczących przewag konkurencyjnych na globalnym rynku usług portowych. Do tego potrzebne jest systemowe podejście obejmujące również współpracę z otoczeniem społecznym czy ścisłe zorientowanie na kwestie ochrony środowiska, w tym kryzysu klimatycznego i zjawisk ekstremalnych z tym związanych.

Celem badania było sprawdzenie jak wygląda prośrodowiskowe podejście krajowych portów morskich do realizacji polityki zrównoważonego rozwoju w oparciu o działania w obszarze społecznym, gospodarczym, środowiskowym i przestrzennym oraz to w jaki sposób umiejscowiona w ich zamierzeniach strategicznych została koncepcja zielonego portu. Ostatecznie do analizy wybrano 13 portów morskich, z czego cztery posiadały status portów o podstawowym znaczeniu dla gospodarki narodowej. Pozostałe dziewięć portów to podmioty o typowo regionalnym i lokalnym charakterze. Wyniki wskazują, że najczęściej tam podejmowane były zagadnienia gospodarczo-przestrzenne. Jest to tożsame z podstawową i tradycyjną działalnością portów morskich, które budowały swój potencjał dzięki aktywności inwestycyjnej i dywersyfikacji oferty usługowej. Rzadziej podejmowano sprawy społeczne oraz środowiskowe. Problematyka umiejscowienia koncepcji zielonego portu dotyczyła zaledwie czterech spośród wszystkich analizowanych przypadków, do których należą porty o strategicznym znaczeniu dla rozwoju gospodarki kraju - zespół portowy Szczecin-Świnoujście, Port Gdynia i Port Gdańsk. 
W ich przypadku podejmowanie zintensyfikowanych działań wykraczających poza granice administracyjne swojego władztwa portowego warunkowane i determinowane jest zagadnieniami konkurencyjności międzynarodowej, szczególnie w regionie bałtyckim, czy kwestiami ekonomiczno-prawnymi.

Ciekawym przypadkiem okazał się port w Ustce, który mimo swojego lokalno-regionalnego charakteru przyjął działania strategiczne w czterech obszarach prośrodowiskowych związanych z otoczeniem społecznym, prowadzeniem odpowiedzialnej działalności biznesowej, prowadzeniem zrównoważonego rozwoju przestrzennego czy spełnianiem wymogów ochrony środowiska.

Przedstawione informacje stanowić mogą podstawę do wnioskowania czy zapewnienie pełnego zestawu działań na czterech wskazanych płaszczyznach prośrodowiskowych można utożsamiać z tym, że port jest zielony. Bez wątpienia uwzględnienie wszystkich składowych w działaniach rozwojowych wskazuje na znaczną świadomość problemu. Niezbędne jest jednak szersze spojrzenie na problematykę kształtowania zrównoważonego rozwoju, uwzgledniającą dedykowane strategie portowe - zielone strategie oraz wdrażanie innowacyjnych rozwiązań i narzędzi prośrodowiskowych. Uzupełnieniem tych działań powinna być m.in. aktywność polegająca na czynnym udziale w zespołach (o różnej randze, w szczególności międzynarodowej), które dzielą się wiedzą oraz dobrymi praktykami związanymi z intensyfikacją działań prośrodowiskowych.

\section{Piśmiennictwo}

Apanowicz J., 2002, Metodologia ogólna, Wydawnictwo Bernardinum, Gdynia.

Bocheński T., Palmowski T., Studzieniecki T., 2021, The Development of Major Seaports in the Context of National Maritime Policy. The Case Study of Poland, Sustainability, 13(22), 1-20.

Cheaitou A., Cariou P., 2019, Greening of maritime transportation: a multi-objective optimization approach, Annals of Operations Research, 273(2), 501-525.

Czarniawska B., 2014, Social Science Research: From Field to Desk, SAGE Publications, Los Angeles.

Davarzani H., Fahimnia B., Bell M. G., Sarkis J., 2016, Greening ports and maritime logistics: A review, Transportation Research Part D: Transport and Environment, 48, 473-487.

Dooms M., 2019, Stakeholder Management for Port Sustainability: Moving from ad-hoc to Structural Approaches [w:] R. Bergqvist, J. Monios (red.), Green Ports: Inland and Seaside Sustainable Transportation Strategies, Elsevier, Amsterdam, 63-84.

Du K., Monios J., Wang Y., 2019, Green Port Strategies in China [w:] R. Bergqvist, J. Monios (red.), Green Ports:
Inland and Seaside Sustainable Transportation Strategies, Elsevier, Amsterdam, 211-229.

EcoPorts, www.ecoports.com [dostęp: 20.07.2021].

EMTER - European Maritime Transport Environmental Report 2021, https://www.eea.europa.eu/publications/ maritime-transport/ [dostęp: 20.07.2021].

Environmental Ship Index (ESI), www.environmentalshipindex.org [dostęp: 20.07.2021].

ESPO Environmental Report 2021, https://www.espo.be/ media/ESP-2844\%20(Sustainability\%20Report\%20 2021)\%20FINAL.pdf [dostęp: 20.07.2021].

Hoyle B., 1989, The Port-City Interface: Trends, Problems and Examples, Geoforum, 20, 429-435.

Komisja Europejska, 2021, Komunikat Komisji Do Parlamentu Europejskiego, Rady, Europejskiego Komitetu Ekonomiczno-Społecznego i Komitetu Regionów w sprawie nowego podejścia do zrównoważonej niebieskiej gospodarki w UE „Przekształcenie niebieskiej gospodarki UE na rzecz zrównoważonej przyszłości", https://eur-lex.europa.eu/legal-content/PL/TXT/?uri=CELEX:52021DC0240 [dostęp: 20.07.2021].

Koncepcja rozwoju Portu Władysławowo, 2019, „,Szkuner" Sp. z o.o, Władysławowo, https://www.szkuner.pl/uploads/ Szkuner\%20-\%20Koncepcja\%20rozwoju\%20Portu\%20-\%202019.07.31\%20gotowy.pdf [dostęp: 20.07.2021].

Lam J. S. L., Notteboom T., 2014, The Greening of Ports: A Comparison of Port Management Tools Used by Leading Ports in Asia and Europe, Transport Reviews, 34(2), 169-189.

Lee P.T.-W., Kwon O.K., Ruan X., 2019, Sustainability Challenges in Maritime Transport and Logistics Industry and Its Way Ahead, Sustainability, 11(5), 1-9.

Lister J., 2015, Green Shipping: Governing Sustainable Maritime Transport, Global Policy, 6(2), 118-129.

Master Plan Portu Morskiego Kołobrzeg, 2019, Zarząd Portu Morskiego Kołobrzeg, Kołobrzeg https://bip.zpm. portkolobrzeg.pl/plik,1815,master-plan-zpm-v-3-0-pdf. pdf [dostęp: 20.07.2021].

Michalski T., 2020, Czy mamy do czynienia z regresem małych polskich portów i przystani morskich?, Prace Komisji Geografii Komunikacji PTG, 23(5), 61-72.

Notteboom T., van der Lugt L., van Saase N., Sel S., Neyens K., 2020, The Role of Seaports in Green Supply Chain Management: Initiatives, Attitudes, and Perspectives in Rotterdam, Antwerp, North Sea Port, and Zeebrugge, Sustainability, 12(4), 1-23.

Obwieszczenie Ministra Infrastruktury z dnia 13 lipca 2021 r. w sprawie ogłoszenia jednolitego tekstu rozporządzenia Ministra Transportu i Gospodarki Morskiej w sprawie utworzenia urzędów morskich, określenia ich siedzib oraz terytorialnego zakresu działania dyrektorów urzędów morskich, Dz. U. 2021 poz. 1339.

Oniszczuk-Jastrząbek A., Pawłowska B., Czermański E., 2018, Polish seaports and the Green Port concept, SHS Web of Conferences 57, InfoGlob, 2-11. 
Palmowski T., 1998, Morskie funkcje Gdyni [w:] E. Adrjanowska (red.), Zespół miejski Gdyni. Przyroda - gospodarka - społeczeństwo, Wydawnictwo Uniwersytetu Gdańskiego, Gdańsk, 111-131.

Parola F., Risitano M., Ferretti M., Panetti E., 2017, The drivers of port competitiveness: a critical review, Transport Reviews, 37(1), 116-138.

Pérez-Lespier L., Long S., Shoberg T., Corns S., 2018, A model for the evaluation of environmental impact indicators for a sustainable maritime transportation system, Frontiers of Engineering Management, 6(3), 368-383.

Plan Rozwoju Portu w Helu, 2009, Zarząd Portu Morskiego Hel KOGA Sp. z o.o., Hel, http://porthel.home.pl/old/ files/plan_rozwoju_portu_w_helu_2009.pdf [dostęp: 20.07.2021].

Plan rozwoju Zarządu Morskich Portów Szczecin i Świnoujście S.A. do roku 2030, 2019, Zarząd Morskich Portów Szczecin i Świnoujście S.A., Szczecin, http://bip. port.szczecin.pl/attachments/download/266 [dostęp: 20.07.2021].

Polityka morska Rzeczypospolitej Polskiej do roku 2000 (z perspektywą do roku 2030), 2015, Międzyresortowy Zespół do Spraw Polityki Morskiej Rzeczypospolitej Polskiej, Warszawa https://www.google.com/url?sa=t $\& r c t=j \& q=\& e s r c=s \&$ source $=$ web $\& c d=\& v e d=2 a h U K E w j$ Hg_LBs4T0AhUlv4sKHVF6AKwQFnoECAYQAQ\&url=htt ps\%3A\%2F\%2Fwww.gov.pl\%2Fdocuments\%2F528248 \%2F541918\%2FPolityka_Morska_RP.pdf\%2Fbe2520f938b9-6e5a-6c65-b49e2f3e6b4d\&usg=AOvVaw2dS1kM Qwg1y0uUt7RaPkhq [dostęp: 20.07.2021].

Rozporządzenie Ministra Gospodarki Morskiej i Żeglugi Śródlądowej z dnia 15 stycznia 2020 r. w sprawie zniesienia Urzędu Morskiego w Słupsku, Dz. U. 2020 poz. 91.

Sage-Fuller B., 2018, The Greening of Ports [w:] M. Salomon, T. Markus (red.), Handbook on Marine Environment Protection, Springer, 793-809.

Strategia Portu Gdańsk 2030, 2019, Zarząd Morskiego Portu Gdańsk S.A., Gdańsk, https://www.portgdansk.pl/documents/2021/01/strategia-2030.pdf [dostęp: 20.07.2021].

Strategia rozwoju portów i przystani morskich południowego brzegu Zalewu Wiślanego, 2016, Actia Forum sp. z o.o., http://tolkmicko-umig.bip-wm.pl/ public/get_file_contents.php?id=331672 [dostęp: 20.07.2021].

Strategia rozwoju Portu Gdynia do 2027 roku, 2014, Zarząd Morskiego Portu Gdańsk S.A., Gdynia, https://www.port. gdynia.pl/o-porcie/strategia-rozwoju-portu-gdynia-do-2027-roku/ [dostęp: 20.07.2021].

Strategia Rozwoju Portu Morskiego Kołobrzeg, 2010, Zarząd Portu Morskiego Kołobrzeg, Kołobrzeg https:// zpmkolobrzeg.pl/zalacznik/1065 [dostęp: 20.07.2021].
Strategia rozwoju portu morskiego w Elblągu, 2019, Zarząd Portu Morskiego Elbląg, Elbląg, http://www.port. elblag.pl/media/_js/filemanager/userfiles/2021/Strategia_rozwoju_portu_Elblg_-_aktualizacja.pdf [dostęp: 20.07.2021].

Strategia Rozwoju Portu Morskiego w Ustce do 2030 roku, 2019, Actia Forum sp. z o.o., https://bip.um.ustka. pl/a,28111,uchwala-nr-xiii1332019-z-dnia-29-pazdziernika-2019-r-w-sprawie-przyjecia-strategii-rozwoju-portu-mor.html [dostęp: 20.07.2021].

Strategia Rozwoju Portu Mrzeżyno, 2010, https://www.

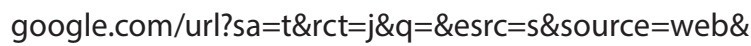
$\mathrm{cd}=\&$ ved=2ahUKEwiUjazDxITOAhUTuosKHfNfBfwQFn oECAMQAQ\&url=http\%3A\%2F\%2Fbip.trzebiatow.pl\% 2Fapi\%2Fdownload\%2Ffile\%3Fid\%3D11097\&usg=AOv Vaw2R-P784hNKDQAKk2PabAdN [dostęp: 20.07.2021].

Szymańska W., Michalski T., 2018, Przekształcenia funkcji polskich małych portów morskich, Prace Komisji Geografii Komunikacji PTG, 21(3), 70-77.

Ustawa z dnia 20 grudnia 1996 r. o portach i przystaniach morskich, Dz. U. 1997 nr 9 poz. 44.

Ustawa z dnia 6 grudnia 2006 r. o zasadach prowadzenia polityki rozwoju, Dz. U. 2006 nr 227 poz. 1658.

Wykaz portów i przystani morskich w kompetencjach terytorialnych Dyrektora Urzędu Morskiego w Szczecinie wraz z informacją o podmiocie zarządzającym zgodnie z ustawą z dnia 20 grudnia 1996 r. o portach i przystaniach morskich (Dz. U. z 2017 r. poz. 1933 oraz z 2019 r. poz. 1716), 2020, Szczecin, http://www.ums.gov. pl/porty/pp_10_2019.pdf [dostęp: 20.07.2021].

Wykaz portów i przystani morskich w obszarze właściwości terytorialnej Dyrektora Urzędu Morskiego w Gdyni oraz informacja o podmiotach zarządzających w oparciu o ustawę z dnia 20 grudnia 1996 r. o portach i przystaniach morskich (Dz. U. 2021 poz. 491), 2021, Gdynia, https://www.umgdy.gov.pl/wp-content/uploads/2021/05/INZ_wykaz_portow_i_przystani_05_2021. doc [dostęp: 20.07.2021].

Zarząd Morskiego Portu Gdańsk S.A., www.portgdansk.pl [dostęp: 20.07.2021].

Zarząd Morskiego Portu Gdynia S.A., www.port.gdynia.pl [dostęp: 20.07.2021].

Żukowska S., 2020, Concept of green seaports. Case study of the seaport in Gdynia, Transport Geography Papers of Polish Geographical Society, 23(3), 61-68.

Żukowska S., 2021a, Changes in the function of former seaport areas using the example of the Dalmor waterfront in Gdynia, Journal of Geography, Politics and Society, 11(1), 27-36.

Żukowska S., 2021b, Zielone porty wobec wyzwań logistyki, Namiary na Morze i Handel, 09, 15-16. 